\title{
Heroes and Victims in Divided Nationalism: The Case of Namibia
}

\author{
Elke Zuern', James M. Jasper ${ }^{2}$ \\ 'Sarah Lawrence College \\ ${ }^{2}$ CUNY Graduate Center
}

\begin{abstract}
Heroes play a role in every nation's founding narrative, embodying a group's strength and courage, its dedication to protecting all within its fold, and its most important traditions and promises. Yet hero images and tropes have not received the attention they deserve in the social science literature on nations and nationalism. Recent theories of character work - the rhetorical construction of heroes, villains, victims, and minions - reveal the challenges of building an inclusive nationalism in post-colonial states. We engage the debates over some of Namibia's most prominent and contested heroes through the memorials dedicated to them and the commemorations honoring victims of past struggles. We study the victims that these heroes sought to defend and trace the process by which victims become heroes of endurance. The Namibian state has, after its recent independence, constructed a memorial to fallen heroes, Heroes Acre, and an Independence Memorial Museum. Alongside these statesanctioned memorial sites, a range of citizens have sought to honor and defend their own heroes. By honoring different heroes, they have defined alternative understandings of the nation. We also demonstrate the power of victims in mobilizing present day campaigns for justice and reparations. In Namibia, as elsewhere, greater attention to victims could shift the balance of political power. This article demonstrates how a focus on struggles over the legitimacy of particular heroes and victims can provide unanticipated insights into the study of divided nationalism.
\end{abstract}

\section{Keywords}

Nationalism; divided nationalism; characters; heroes; victims; post-colonial; reparations; memorials; Namibia

Heroes play a role in every nation's founding narrative. They demonstrate the nation's greatest strengths at challenging, do-or-die moments. Their courage and abilities in fighting for their people help to establish that people as a collective, inspiring a nation into being after the fighting stopped. Heroes

\footnotetext{
* Elke Zuern (corresponding author), Politics, Sarah Lawrence College, 1 Mead Way, Bronxville, NY 10708, United States, ezuern@sarahlawrence.edu; James M. Jasper, Department of Sociology, CUNY Graduate Center 365 Fifth Ave, New York, NY 10016, USA, JJasper@gc.cuny.edu.
} 
demonstrate the most positive attributes of a nation, its perseverance, its dedication to protect all within its fold, its most important traditions, and promises. Yet hero images and tropes have not received the attention they deserve in the social science literature on nations and nationalism. A number of celebrated works have explained and analyzed the rise of modern nationalism almost solely through agentless macro-historical changes: the development of capitalism, secularism, technology, and state bureaucracy (Gellner 1983; Hobsbawm 1992; Anderson 1991). Benedict Anderson's Imagined Communities, for example, despite recognizing the role of literary imagination in myth making, only considers "anonymous" and "faceless" heroes in the construction of nationalism. He highlights the role of cenotaphs and tombs of Unknown Soldiers as key to the construction and imagination of modern nations: "The public ceremonial reverence accorded these monuments [is] precisely because they are either deliberately empty or no one knows who lies inside them" (Anderson 1991, 9).

Anonymity may allow an unidentified fatality to represent the whole nation, but it also draws attention away from the traits that can make wellknown individuals into compelling heroes. Anthony Smith, whose Ethnic Origins of Nations rejects "modernist" approaches, focuses his attention on the ethnic building blocks of nationalism. In contrast to Anderson's emphasis on anonymity, Smith notes the impact of specific heroes and their acts of resistance. "The heroes, like the history, can only be understood ... as epitomizing and crystallizing the presumed virtues and qualities of the particular community" (Smith 1986, 200).

This specificity of individual nation-building processes along with their particular heroes and villains, led many post-colonial thinkers to bristle at the suggestion that modular nationalism as envisioned in Europe should also apply to the rest of the world. Western European nationalism was not built on the inclusive and democratic principles that its eulogizers had often claimed (Marx 2003). Post-colonial societies have forged their own forms and approaches to nationalism, in a break from key aspects of the European and American models, even as they built their nation on other aspects. Partha Chaterjee famously complained: "Europe and the Americans, the only true subjects of history, have thought out on our behalf not only the script of colonial enlightenment and exploitation, but also that of our anticolonial resistance and postcolonial misery" (Chaterjee 1993, 5). Nations fighting for independence and those that had recently won it demanded their rights to define their own heroes. 
Newly independent states faced the challenge of forming a "new" nationalism that united people within what were often colonial-era boundaries. They needed to engage multiple precolonial and colonial experiences as well as to resolve competing ideas of what the new nation should be. Where a single liberation movement successfully wrested power from the previous colonizers, their leaders, often a single leader, was presented to the new nation as the national hero (Southall 2013). But they never fought alone, nor were they universally accepted. At times, they were not even embraced by an overwhelming majority. There were other heroes within the same party. There were anti-colonial heroes outside the dominant liberation movement, some who even fought against it. And then there were the heroes of the previous colonial state and their supporters. The messiness of these competing actors and the ideals they represent play out most visibly in debates over monuments. Which heroes should be cast in bronze to embody the nation? Which heroes should receive the most prominent spot? Which old monuments should be removed? Where and how might they be laid to rest? These questions confront all new regimes, and old ones as well.

Heroes define the nation and victims embody the injustices the nation must address. Victims' power lies initially in inspiring others to action. This may occur through their recalling of the crimes committed against them, images depicting their physical suffering, or the presentation of their mutilated bodies. Jo Becker, reflecting on her work at Human Rights Watch, highlights the power of victims. She details the campaign to bring Charles Taylor to justice for war crimes and crimes against humanity, a process that was complicated by the fact that Taylor was the sitting president of Liberia and had been granted asylum in Nigeria. A coalition of activists attempted to pressure the Nigerian government to revoke his asylum, but failed. Then, two Nigerian men who had been mutilated filed suit in Nigeria's Federal High Court (Becker 2013, 115-116). Their detailed testimony proved crucial.

Taylor was returned to Liberia and then to The Hague to stand trial. $\mathrm{He}$ was found guilty of war crimes and crimes against humanity and sentenced to fifty years in prison. Taylor became the first former head of state found guilty of war crimes by an international tribunal since the Nuremburg Trials of Nazi leaders. The testimony of victims was crucial to his extradition and trial. Ronald Niezen argues: "Provoking emotions in sympathetic others calls for tangibility and intimacy and the innocence of sufferers, all of which are absent when a crisis exists only as an injustice, as words on paper" (Niezen 2010, 47). Like heroes, victims can profoundly shape our understanding of history and its significance. 
We draw on recent theories of character work - the rhetorical construction of heroes, villains, victims, and minions - in order to understand the challenges of building an inclusive nationalism in post-colonial states (Jasper, Young, Zuern 2020). Narrative and other cultural tools place characters at their center, because these characters give stories much of their emotional punch. The characters are distinguished by two binaries, strong versus weak and good versus bad. Heroes are strong and good, villains strong but bad; victims are weak and good, minions weak and bad. These characters tell audiences what they should feel about each character: gratitude and admiration for the heroes who save and protect them; fear, loathing, and outrage toward the villains who threaten them; pity for those who are weak and suffering; ridicule for the minions who are malevolent but too weak to be threatening, unless and until they are massed together in large numbers and led by a true villain. These characters can be defined through stories, but also via sculptures, cartoons, music, and other media.

We trace the debates over some of Namibia's most prominent and contested heroes through the memorials dedicated to them and the commemorations around these memorials. We consider the victims that these heroes sought to defend and analyze the process by which victims have become "heroes of endurance." We focus on monuments built a century ago by the German colonial state and those built since independence in $1990 .^{2}$ After the end of South African rule and apartheid, the newly independent Namibian government initially decided not to remove German colonial monuments (Steinmetz and Hell 2006, 158). While this protected much of the German memoryscape, the government has added new memorials to dramatically present its post-colonial narrative, and non-state actors have built memorials to commemorate their own unrecognized heroes. Memorials are a site for contestation, performance, and debate as activists challenge the persistence of old inequalities and the slow pace of change.

While others have examined the commemoration of heroes in Southern Africa, we present heroes as part of a broader typology of characters that shift and expand as dominant historical narratives are challenged. With successful liberation struggles, colonial villains became postcolonial heroes. With an expansion of narratives, the suffering of victims gains attention. Alongside traditional heroes, we consider the significant role of victims and those whom we define as heroes of endurance: those who win in the long run by enduring hardships. We demonstrate the continuing power of victims in mobilizing

2 Based on Elke Zuern's fieldwork in Namibia and Germany between 2007 and 2019 as well as attendance at court proceedings and news conferences in New York in 2018 and 2019. 
campaigns for justice. In Namibia, as elsewhere, greater attention to victims could shift the balance of power but also further divide the nation. They provide the evidentiary - and emotional - basis for claims for truth and justice as well as reparations. Their power is demonstrated both in courts of law and in the court of public opinion.

Our work builds on contributions from scholars such as Werbner's (1998) writings on the memorialization of heroes in Zimbabwe and Becker (2011), Gewald (1999), Kössler (2007) and Zuern's (2012) writings on Namibia as well as Saul and Leys (2003) and Melber's (2005) powerful critique of the exclusive nationalism of Namibia's liberation movement. But, none has considered heroes within a broader framework of character work, and none has focused on how heroes build on the roles that other characters play. The crucial question is not just: which heroes are celebrated? We must add: how do these heroes change over time? Which victims are recognized? Which injustices are publicly discussed? Who might be held responsible for the suffering of these victims? We explore these questions in the following pages.

\section{Memorializing Heroes}

At least since Ramses II and the Emperor Augustus, states have erected stone and metal memorials to heroes and leaders, seeking to present a common ideal for the nation. The stronger and more moral the founding heroes appear, the more lasting and admirable the nation they create. But the meanings of heroes change over time, often as a result of assiduous character work. In the United States, the Lincoln Memorial serves as one prominent example. The inscription behind Lincoln notes: "In this temple as in the hearts of the people for whom he saved the Union the memory of Abraham Lincoln is enshrined forever." The emphasis, originally, was on the Union. This was not intended to be a memorial to emancipation or racial unity. It was, however, employed in this way by civil rights activists, culminating in Martin Luther King Jr.'s (MLK) "I have a dream" speech in front of the imposing memorial (Snee 2015). With the 2003 addition of a plaque on the steps of the memorial where MLK stood, Snee argues, "A memorial built for one man had become a sacred space that honored two, and its dominant meaning had shifted from the Civil War to civil rights" $(2015,143)$. In 1963, a living hero drew on the power of a past hero to build upon the nation's achievements and to redefine the nation.

One aim of character work is to stabilize symbols of good and evil: heroes are reliably, thoroughly, unquestionably strong and good, villains predictably strong and bad; victims are morally worthy and innocent but too weak to protect themselves. Character work takes such tropes out of the vicissitudes 
of history, essentializing them. They are cast in bronze and carved in marble, meant to last forever. Savage argues: "The impulse behind the public monument was an impulse to mold history into its rightful pattern. And history was supposed to be a chronicle of heroic accomplishments, not a series of messy disputes with unresolved outcomes" $(1997,4)$.

But history is messy. One player's hero is another's villain. In the aftermath of the 2015 Charleston massacre, U.S. cities from Memphis to New Orleans removed statues of Confederate leaders, which had become focal points of contention as a new generation of activists drew increased attention to ongoing racial injustice. The removal of memorials in some states signals the potential power of a new narrative, as in Eastern Europe after 1989. But change is most often contested and incremental. By early 2019, according to the Southern Poverty Law Center (2019) while over "100 monuments and other symbols of the Confederacy have been removed... 1,747 Confederate monuments, place names and other symbols" remain in public spaces. In mid 2020, after a white police officer killed George Perry Floyd Jr., popular protest in defense of black lives reached new heights and more Confederate monuments were removed.

The very definition of heroes can change over time, especially as they have lost some of their divine aura. According to Barry Schwartz, the United States and many European countries have entered a "post-heroic" era. He describes the ideal type of a traditional national monument, intended to celebrate founding heroes: "a statement engraved on the monument describing the cause for which it was built, idealistic human representation, larger-than-life physical dimensions, vertical preeminence, centrality and prominence of placement, lightness of color, grandness of size, prominence of national symbolism" (Schwartz 2008, 187). He contrasts these with more recent monuments of the post-heroic era: "absent or ambiguous statements about cause, abstractness of representation, horizontal lines (often walls hugging the ground or placed below ground), inconspicuous placement, darkness of color, smallness of size, want of national symbolism"(188). It may turn out to be that the difference is not one of era, but of purpose: founding moments still need heroic monuments, as we see in Namibia. Even neighboring South Africa with its many abstract memorials is dotted with heroic statues and busts of Nelson Mandela (Marshall 2010).

Namibia's transformation from German protectorate to South Africanruled apartheid state to independent country necessitated radical changes in governance and in its official cult of heroes. While its state-endorsed national heroes changed suddenly, monuments across the country honoring past heroes remained frozen in stone dramatically presenting the heroes and 
ideals of different eras. They outlasted the power of those who constructed them, leaving the postcolonial state with the question of what to do with monuments honoring their former oppressors (Grabar 2014; McGarr 2015). The public debate over these memorials demonstrates the political importance of national heroes to all who seek to honor, challenge, or reframe them. While the cast of heroes and villains from the era of German rule to the present day has changed dramatically, each government's and its challengers' desire to present its own heroes have not.

\section{German Colonial Memorials in Independent Namibia}

At the dawn of independence in 1990, Namibia's capital, Windhoek, seemed to be filled with memorials of German rule even though Germany had lost control of its colony after its defeat in the First World War. The South African government assumed control of the territory, first under a League of Nations mandate and later under a United Nations Trusteeship. It instituted apartheid in Namibia and left German memorials in place.

German colonial era memorials such as the Reiterdenkmal (Equestrian Monument) in central Windhoek and the Marine Memorial in coastal Swakopmund depict classic heroes: muscular young men, gun in hand, ready to fight. They brave the elements to continually stand guard, gazing out across the land watching for foes. These memorials are meant to symbolize strength, bravery, and persistence, but they also acknowledge some of the casualties of war. The Reiterdenkmal did this subtly by commemorating the dead on a plaque on its base. The Marine Memorial does this more dramatically not only by including a plaque listing the German dead but by depicting a fallen soldier lying on the memorial itself. The fallen hero's wrecked body powerfully demonstrates the sacrifices that heroes make. The memorials celebrate German military strength, victory in war, and the brutal defeat of indigenous resistance. The victims of their actions are unacknowledged. But, as we will see, victims also play a crucial role in constructing a nation's narrative and defining its future.

Colonization is violent by definition, but the German conquest of Namibia was among the most brutal. When the German-Herero ${ }^{3}$ war began in Okahandja in January 1904, the Ovaherero initially had the advantage. But by August, reinforced German troops defeated the Ovaherero and forced them to retreat into the Omaheke desert in the east, where the majority of people and their

3 Herero is used here interchangeably with Ovaherero. 
Journal of Nationalism, Memory \& Language Politics 14(1)

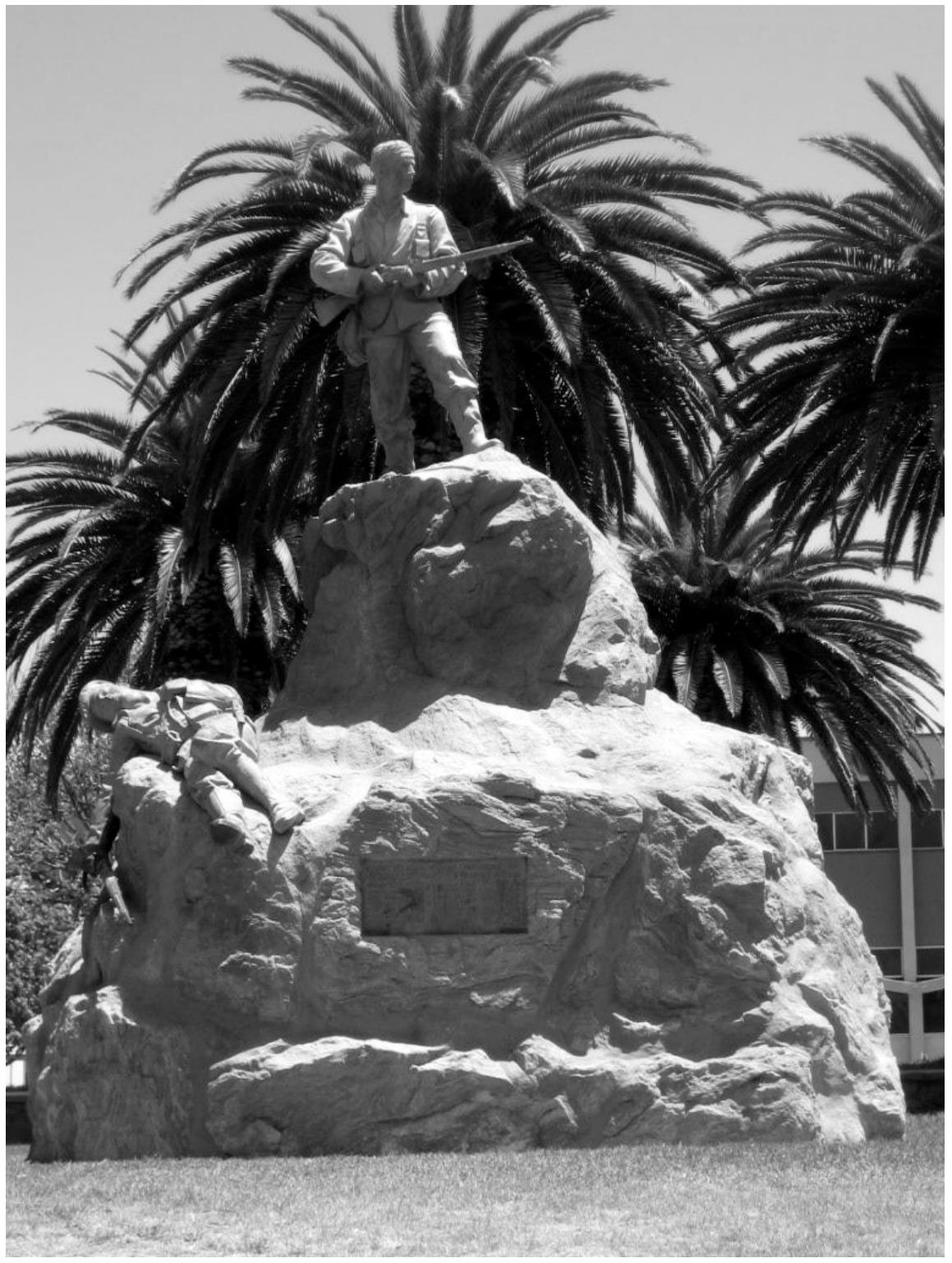

Marine Memorial_Swakopmund (2008) 
cattle died. General Lothar von Trotha then issued his infamous genocide order:

"I, the great General of the German troops, send this letter to the Herero... The Herero people must leave the land... Within the German borders every Herero, with or without a gun, with or without cattle, will be shot. I will no longer accept women and children; I will drive them back to their people or I will let them be shot at" (quoted in Olusoga and Erichsen 2010, 149-50).

$\mathrm{He}$ also issued an extermination order against the Nama. ${ }^{4}$ After defeating both Nama and Ovaherero armies in battle, German forces set up deadly concentration camps in major towns across the country. In total, up to 80 percent of the Ovaherero were killed and an estimated 50 percent of the Nama people also died (Gewald 2000; Erichsen 2008). Today, these events are recognized as genocide not just by academics (Bley 1968; Drechsler 1980; Gewald 2003; Böhlke-Itzen 2004; Zimmerer 2004) but also, belatedly, by the German government (Wieczorek-Zeul 2004; Olusoga 2017).

The Equestrian Monument stood on the site of the largest of the Germans' five main concentration camps. Debates over what to do with a monument on such a prominent and historically significant location had risen repeatedly (Melber 2005, 110), but it was not until the monument's location obstructed the planned Independence Memorial Museum that the government took action. When the government revealed its plan to remove the monument in 2008, the pages of the minority German-language newspaper, the Allgemeine Zeitung $(A Z)$, filled with articles criticizing the move, mobilizing supporters first to try to stop the move and later to raise funds to preserve the monument. ${ }^{5}$ The paper published ten articles in June 2008 alone, including German-Namibian Andreas Vogt's long, impassioned critique published in three separate articles. His articles led to an increase in letters from both Namibia and Germany criticizing the proposed move. Many $A Z$ readers seconded Vogt's arguments concerning the cultural and historical significance of the monument and also argued that the Equestrian Monument was a major tourism draw for

4 "The Nama who chooses not to surrender and lets himself be seen in Germany territory will be shot, until all are exterminated. Those who, at the start of the rebellion, committed murder against whites or have commanded that whites be murdered have, by law, forfeited their lives. As for the few not defeated, it will fare with them as it fared with the Herero, who in their blindness also believed that they could make war successfully on the powerful German Emperor and the great German people. I ask you, where are the Herero today? - Lothar von Trotha" poster at the "International Law and Justice in Postcolonial Contexts" conference Swakopmund, Namibia: March 27-29, 2019.

5 Of the four national dailies (the state-owned, English language New Era and the privately owned Namibian, the German language Allgemeine Zeitung (AZ) and the Afrikaans language Republikein), the $A Z$ followed the story of the impending move of the Equestrian Monument by far the most closely and critically. The Namibian's published articles were all broadly supportive of the move but raised concerns regarding process, consultation and cost. 
Namibia. This was followed by an online reader poll, later expanded to the paper copies of the newspaper, which was overwhelmingly against the move. The $A Z$ published updates on the poll every few days until it finally claimed that over 98 percent of German-speaking respondents were against the move (Allgemeine Zeitung August 18, 2008). A number of German-Namibians expressed a certain colonial nostalgia lamenting the loss of German control as well as their diminishing influence in present day Namibia (Kössler 2007; Steinmetz 2008). The unilateral decision by the cabinet to remove the memorial had demonstrated German-Namibians' dramatically reduced political power.

While German-speakers were the most active in resisting the move, they were not the only ones who opposed it. A number of leading Ovaherero politicians including Deputy Minister Kazenambo Kazenambo and opposition politicians Katuutire Kaura and Ovaherero Paramount Chief Kuaima Riruako argued that the Rider was an important reminder of German aggression and war crimes (Zuern 2012, 507). Kazenambo argued that the monument "is a reference point, a reference of colonial engagement" (quoted in New Era June 23, 2008). Similarly, Katuutire Kaura, whose ancestors were imprisoned by the Germans during the 1904-1908 war, also called for the monument to remain (The Namibian July 11, 2008). Finally, Ovaherero Paramount Chief Kuaima Riruako argued that the horse should stay to remind everyone what the German colonial state had done in Namibia (Allgemeine Zeitung June 25, 2008). For them, the Rider was a useful villain.

Villains always have victims. For those who knew the history of German actions in colonial South West Africa, the Rider stood as a reminder of the unacknowledged victims of genocide. In this way, the Rider was also a prominent symbol for Ovaherero and Nama claims for reparations. The Namibian government, while supporting demands for Germany to formally recognize the Ovaherero and Nama genocides, has not supported calls for reparations that would be paid directly to minority communities. The government instead sought greater foreign aid to be paid to the Namibian state to distribute as it deemed most beneficial to the country as a whole. The competing goals of government and opposition actors have led one to downplay past victimhood and the other to emphasize it.

\section{From Villains to Heroes: Representing Liberation}

With Namibia's independence, former freedom fighters once labeled as terrorists became Members of Parliament, Deputy Ministers, Ministers, and President. The colonial and apartheid regimes' villains were now the 
democratically elected representatives of the people. The new president, Sam Nujoma, had led the largest liberation movement in Namibia, SWAPO, spearheading three decades of struggle against oppression. He now headed the dominant party (SWAPO Party) in the legislature and with that, the state, as it charted a new course (Melber 2015). He and his allies created a new nation. The president conceived the idea of the first large-scale, governmentcommissioned memorial project in 1997 when he visited Zimbabwe for an African Union summit meeting (Becker 2011, 525). Namibia’s Heroes Acre is modeled on Zimbabwe's memorial of the same name. Both were built by the same North Korean company, Mansudai Overseas Projects, specialists in social-realist sculptures of heroes (Van der Hoog 2019). Namibia's national monument park is situated six miles south of central Windhoek. The location is noteworthy. It is not easily accessible to ordinary citizens as there is no regular public bus service to the site.

Those who reach the site by car, taxi, or chartered bus pass through an imposing entrance gate and drive up a wide road to the main memorial site, a vast, open space. A long series of steps leads the visitor past rows of individual gravestones dedicated to fallen heroes, finally reaching the central monument, the Unknown Soldier. The base of the statue alone is about ten feet high, made of smooth marble pitched at a steep incline offering little opportunity to those who might consider scaling the base to reach the monument. The heroes here are untouchable. The towering Unknown Soldier, standing atop the base, holds a gun in one hand and is ready to throw a grenade with the other. Behind him, an obelisk over 100 feet high, representing a sword, thrusts toward the sky.

The Unknown Soldier offers the visitor an image of the nation, for which ordinary individuals sacrificed their lives, not for king and empire, as in Westminster Abby, but for "justice and freedom." The eternal flame, like that in Paris, Arlington, and so many other sites, defies wind and rain. Like the colonial era locations described by Anderson, the site is sanitized and controlled by guards at the front gate, so that no unauthorized commemorations can take place (Anderson 1991, 182). But, belying Anderson's argument for the power

6 The inscription on the stone capping the grave in Westminster Abby commemorates: the many multitudes who during the Great War of 1914-1918 gave the most that man can give life itself for god — for king and country — for loved ones home and empire for the sacred cause of justice and freedom in the world 
Journal of Nationalism, Memory \& Language Politics 14(1)

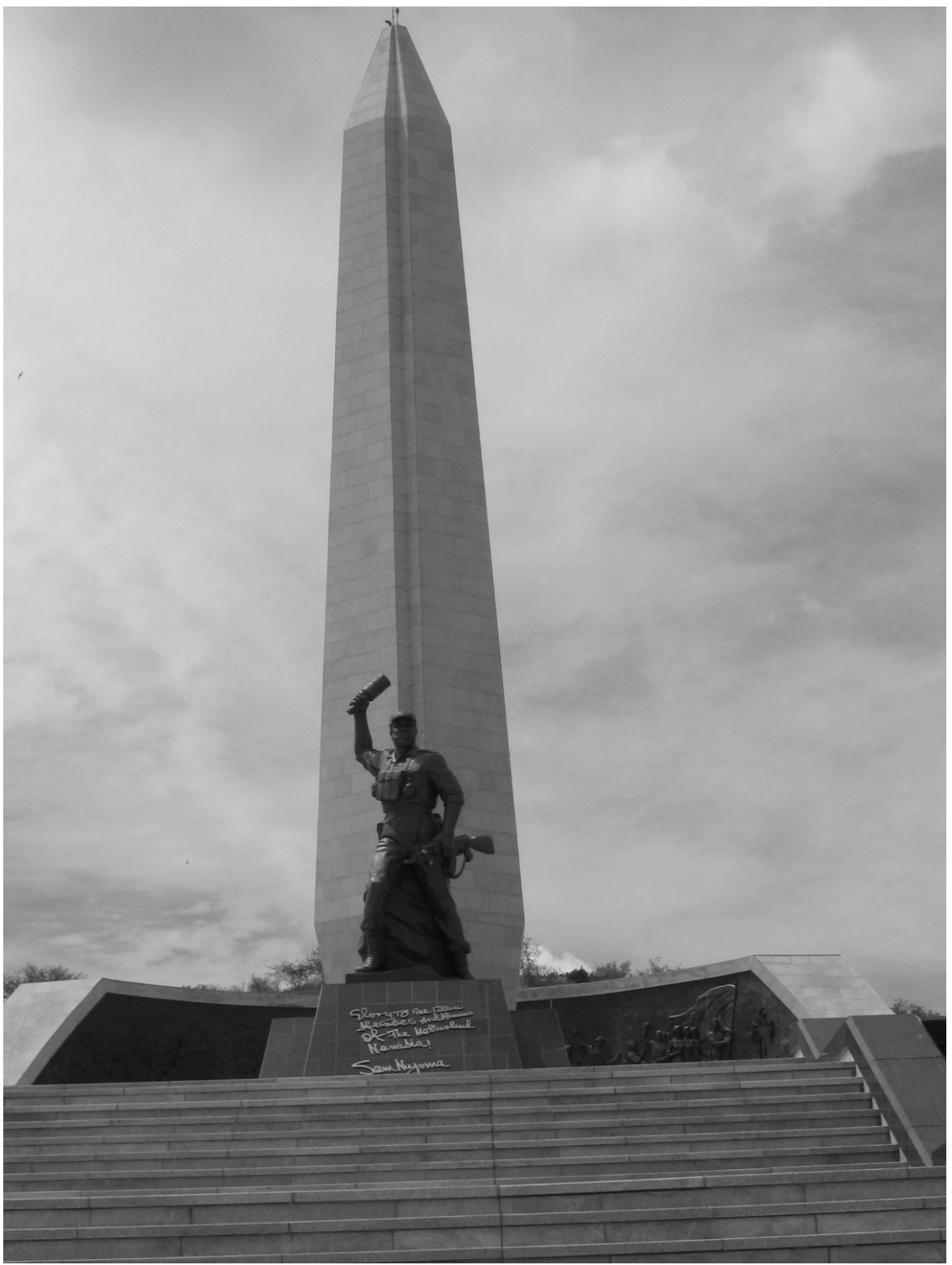

Unknown Solider at Heroes Acre (2008) 
of the anonymous hero, the Unknown Soldier bears a strong resemblance to Sam Nujoma, reminding the visitor exactly whom to revere.

Heroes Acre was built to foster a state-sanctioned nationalism, but few Namibians visit. Every time one of the authors visited the site, it was empty except for the guards. Within a few years of its opening, the National Heritage Council reported only 7,533 visitors a year (The Namibian October 19, 2006). By 2017, the site manager, Helena Neugola, commented: "It is very disappointing to see that our Namibian people rarely come" and the stateowned New Era newspaper described Heroes Acre as an "unexplored gem" (July 4, 2017). It remains a key location for state celebrations of heroes through burials of recently deceased SWAPO members despite the controversies that these burials sometimes elicit both within and outside SWAPO. ${ }^{8}$

In 2014, a second significant memorial was inaugurated in Windhoek, this time in the city itself. The new Independence Memorial Museum was built and designed by the same North Korean company. It offers a similar socialist realism in both the unwelcoming architectural style of the building and the realist murals inside depicting some of the worst horrors of colonialism and the struggle for independence (Hopwood 2014). Heroes, villains, and victims are starkly displayed. On the first floor, devoted to "colonial repression," the visitor is greeted by colored bronze busts of early resistance leaders, Chief Samuel Maherero, Kaptein Hendrik Witbooi, and Chief Iipumpu ya Tshilongo. These leaders represent the Ovaherero, Nama, and Ovambo communities, the three largest indigenous language groups in Namibia, although the Ovambo are by far the most numerous. Behind them are pictures of these leaders and others from the period. Displaying these great leaders as busts, however, has the effect of making them seem passive, despite the determined look on their faces. Immobile and frozen in time, they appear less heroic.

As the visitor climbs to the second floor, she is met by an armored vehicle and display cases of weaponry. There are images of the People's Liberation Army of Namibia (PLAN, SWAPO's military wing) troops "in the field." In contrast to the static busts of early resistance leaders, here we see leaders as heroes in action. They appear far more powerful and victorious. Victims are

7 The inscription below the Unknown Soldier reads: "Glory to the fallen heroes and heroines of the motherland Namibia! Sam Nujoma 26th August 2002”, further reinforcing the connection to the country's first president.

8 Leaders including SWAPO co-founder Herman Andimba Toivo ya Toivo, former Prime Minister Theo-Ben Gurirab and long-time SWAPO member then opposition party presidential candidate Hidipo Livius Hamutenya among others have been buried at Heroes Acre. A number of prominent figures (or their families) have resisted being buried there including war veteran Simeon Lineekela "Kambo" Shixungileni and Ovaherero Paramount Chief Kuaima Riruako. 
presented in a series of realist paintings and reliefs. These unnamed civilian victims, particularly women and children, are presented in agony, sometimes dead, sometimes alive. A child screams. Many bleed. The so-called Chamber of Horrors depicts the barbarity of the genocides of the Ovaherero and Nama. Victims' faces show their anguish and pain, others lie motionless, already dead. Some have been hanged and some are in chains. It is these unfortunate souls whom the heroes struggled to liberate in life or death.

Responses to the museum have been mixed. Public commentary in Namibian newspapers has praised the addition of an independence museum to present the country's successful fight for liberation (Mupetami 2014). Upon leaving the museum in March 2017, one of the authors asked a young man nearby what he thought of the museum. He commented: "It's really something. You can go there and be free." Many comments by Namibian-based visitors writing in the museum's guest book also note their appreciation for a museum of liberation. But the guest book includes critiques as well. Former television anchor Norah Apollus who grew up within SWAPO wrote: "Without the valiant women of Namibia we would perhaps not be enjoying our freedom today. It is with utter shock, disbelief and deep disappointment that no where, but no where is there an exhibition dedicated to women. ... SHAME ON YOU!!!"”10

Outside the museum, another statue of former President Sam Nujoma stands prominently, holding the constitution. As explained by his successor, President Pohamba, at the museum's inauguration, this symbolized "a new era of constitutionalism, rule of law, as well as the protection and enjoyment of the fundamental human rights by all our citizens in a free and democratic Republic" (Pohamba 2014). But the statue's size and the massive base upon which Nujoma stands, render him untouchable. The constitution, it seems, is held at a distance. The imagery here is contradictory as it presents the key document of the democratic nation, focused on rights, but perhaps inaccessible to the ordinary citizen. Overall, the symbolism of the museum is clear. Independence has been won through a long and difficult struggle. Many fought; many died. One in particular led. This is the cult of the liberation hero echoing the narrative presented at Heroes Acre.

As part of building the Independence Memorial Museum, the German Equestrian Monument that had been the subject of so much debate, was removed from its original spot in 2009. It was relocated, with private funds, to a new but still prominent position overlooking Windhoek in early 2010. It

9 Author fieldnotes, Windhoek (March 14, 2017).

10 Author fieldnotes, Independence Memorial Museum (May 19, 2014). 
Elke Zuern, James M. Jasper Heroes and Victims in Divided Nationalism: The Case of Namibia

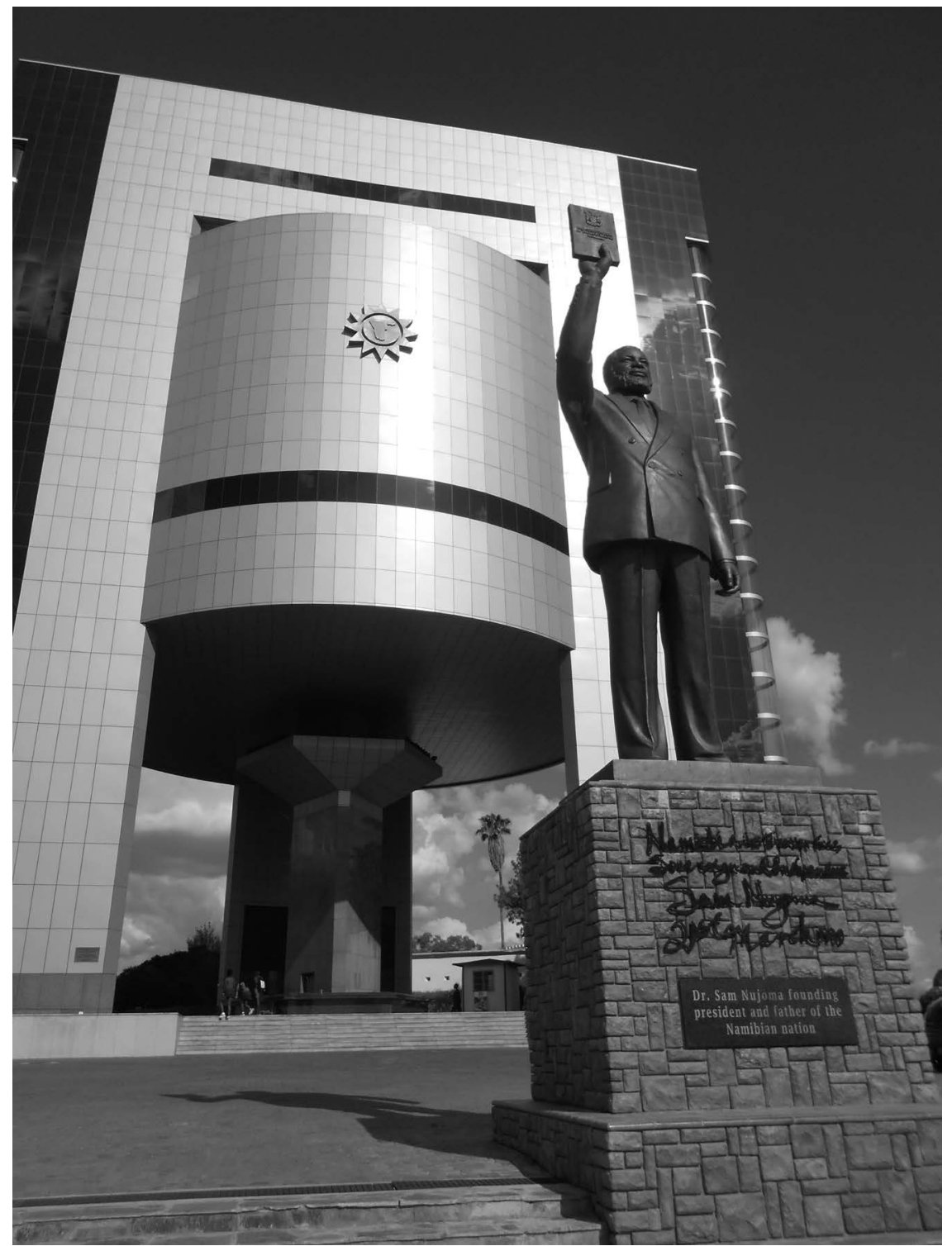

Sam Nujoma in front of the Independence Memorial Museum-Windhoek (2014) 
stood to see the building of the Independence Museum as it rose above the city. Then, under cover of darkness on Christmas night 2013, it was removed. While the move elicited outrage in the pages of the German language newspaper, the $A Z$, the storm died down amidst holidays, summer vacation, and the beginning of a new year. In May 2014, the monument reappeared inside the Alte Feste (German colonial era fort), where it had seemingly taken cover from the imposing museum that had pushed it from its prominent position. The Rider now looks up toward the Independence Memorial Museum, seemingly acknowledging the new state narrative, which dwarfs the German colonial era memorials.

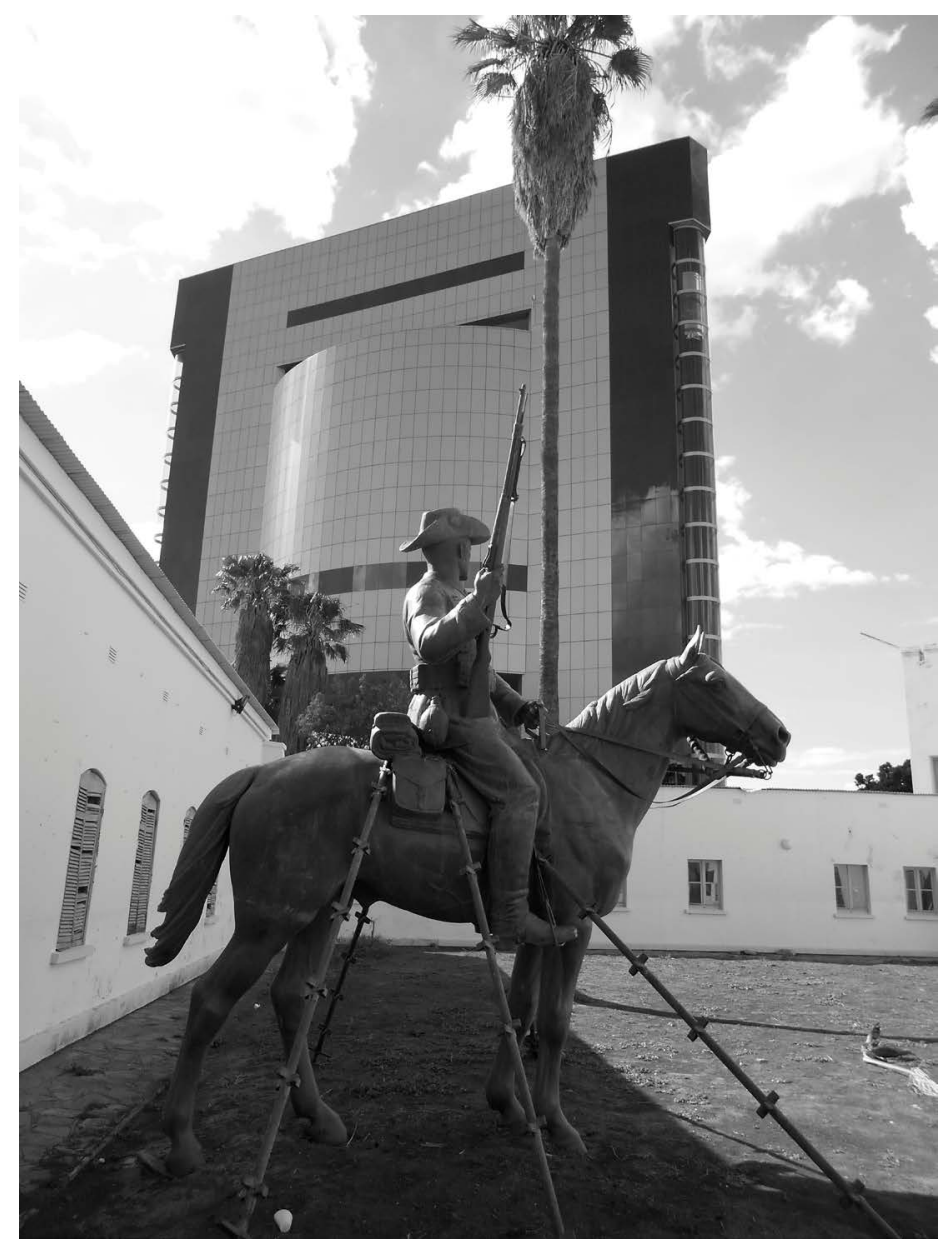

German Equestrian Monument inside the colonial fort_-Windhoek (2014) 


\section{Alternative Heroes and Heroes of Endurance}

The dominant state narrative of liberation is just that: the state narrative. Its large-scale dramatic presentation does not necessarily translate into popular enthusiasm. As Namibian visitors fail to arrive at Heroes Acre and a prominent citizen writes "SHAME" in the Independence Memorial Museum's guest book, we see that this presentation of heroism does not fully resonate. Activist groups, notably the Parents' Committee and Breaking the Wall of Silence, repeatedly called for investigations into the disappearance of activists who joined SWAPO during the struggle against apartheid. One particularly motivated activist, Phil ya Nangoloh, as head of Namibia's National Society for Human Rights, filed papers with the International Criminal Court asking it to open a case to investigate SWAPO's alleged crimes. ${ }^{11}$ The ICC declined the request.

Heike Becker has detailed other ways in which ordinary people have publicly questioned the state's liberation narrative, and the state has acknowledged some of their concerns. In 2005, a construction crew unearthed two mass graves at Eenhana in the far north of the country. As Becker recounts, this opened a national conversation about the victims of the liberation struggle and the prominent but often unrecognized role of civilians. A Memorial Shrine was built at the site. This shrine, along with the President's speech at its inauguration recognized not just the PLAN fighters who had lost their lives but also the civilians who had aided and often buried them. The memorial includes a statue of a female fighter holding the Namibian national flag as well as a second bronze sculpture of three civilians carrying ammunition and food to combatants (Becker 2011, 534). This statue is, according to Becker, the first in Namibia to present civilians not as hapless victims but as agents in action working to change history.

Across cultures, women are often celebrated as heroic in protecting their families, helping resistance fighters, and generally surviving many hardships. In long guerilla wars, simply surviving oppression and violence can turn victims into heroes. We term them "heroes of endurance." They emerged in the twentieth century especially during colonial insurgencies. Heroes of endurance are one rhetorical solution to the hero-victim dilemma: "If you look too strong, you do not seem to need the help of others; if too weak, you become victims and cannot do anything for yourselves. Both extremes have advantages as well as disadvantages: a sense of strength gives confidence and a feeling of inevitability, an image of weakness elicits compassion and aid from others" (Jasper, Young, Zuern 2018, 117). Heroes of endurance gain

11 Author interview, Phil ya Nangoloh, Windhoek, Namibia (March 16, 2017). 
the admiration due heroes but also the sympathy due victims. At Eenhana, they stand alongside more traditional military heroes without significantly undermining the master narrative.

Ovaherero and Nama presentations also challenge the dominant state depiction of SWAPO as the central liberator and representative of the entire Namibian nation by offering their own alternative military heroes. This contestation can be seen in the celebrations of Heroes Day, a national holiday in Namibia. The date for Heroes' Day was chosen by the government to mark the beginning of combat between SWAPO and South African forces in the north of the country in 1966. There are, however, alternative heroes' days. There is the Heroes' Day observed by Nama-speaking communities to commemorate the death of Kaptein Hendrik Witbooi, who led the first armed resistance to the colonial forces. ${ }^{12}$ He died in 1905 fighting German forces. Among Otjiherero speakers, numerous Heroes' Days celebrate leaders who led the fight against the German forces. Red Flag Day is the largest held on the weekend closest to August 26 to mark the anniversary, not of SWAPO's fight, but of Samuel Maharero's burial in Okahandja in 1923 (Förster 2010).

Maharero's funeral commemoration encourages a reassertion of Ovaherero identity and pride and the reestablishment of Ovaherero traditions (Gewald 1999, 22-29). Speakers narrate the history of suffering after the defeat at the battle of Hamakari at Waterberg. In 1904, German forces pursued the Ovaherero into the desert. Survivors trekked into present day Botswana, fled to South Africa (where many worked in dangerous conditions in the mines), or headed north into Ovamboland (within the borders of present day Namibia). A smaller number took shelter in the Khomas Hochland mountains near Windhoek (Gewald 1999, 175-191). After 1904, large numbers of people were interred in concentration camps with incredibly high death rates. Despite their poor health, prisoners were also forced to labor. At commemorative events such as Red Flag Day, stories of Ovaherero survivors are retold. The narratives present the Ovaherero people as courageous and strong in contrast to the brutal German troops. Although the history is one of great suffering, it is the story of small victories and ultimate survival as well as a call for unity. By publicly presenting the struggles of survivors of the genocide, potential victims turned survivors are redefined as heroes of endurance.

Goliath Kaune, a speaker at the 2008 Red Flag commemoration, argued that despite von Trotha's incredible violence, he was a failure. "Von Trotha failed

12 Witbooi has also been prominently honored by the state. From 1993, his image appeared on all Namibian bank notes. In 2012, Sam Nujoma's image replaced Witbooi on the popular N\$10 and N\$20 notes. 
in his objective to decimate the Herero people." ${ }^{13}$ This character work presents the villain who had issued the declaration of genocide as weakened by the incredible resolve of the Ovaherero to survive as a people. This strong sense of Ovaherero identity, despite significant rifts among Ovaherero organizations, has served as an example to other communities who seek to bring their history to greater local and international attention (Erichsen 2008, 48). The Ovaherero remember their heroes. Their stories of action and survival stand in stark contrast to the overwhelming images of victimhood presented in the Independence Memorial Museum and the Genocide Memorial erected by the Namibian state.

\section{The Power of Victims}

Heroes' Day celebrations in Ovaherero and Nama communities celebrate these alternative heroes and heroes of endurance while they also mourn those who died as a result of German aggression. These victims have great potential power, as they are victims of genocide at the hands of the German state, a state that has set precedents by paying reparations to survivors of the Holocaust (Sarkin and Fowler 2008; Springer, Rodriguez and Kamatuka 2017). In Namibia, Ovaherero and Nama descendants of these victims comprise minority communities. Some of their leaders have also led opposition parties challenging SWAPO Party's political dominance. This adds to the political contestation over genocide claims. Activists in Namibia and beyond have demanded a public apology from the German government as well as reparations. ${ }^{14}$ While the German and the Namibian governments have sought to define alternative settlements, the presence of victims has significantly strengthened the activists' case.

In Namibia, descendants of victims of the German genocide have demanded greater public recognition by publicly presenting their history. Activists erected a memorial stone recognizing victims of genocide on Shark Island and another in Swakopmund Memorial Park acknowledging that the victims died "in concentration camps" in "the realm of their German colonial masters" (Zuern 2012). Others splashed red paint on the Marine memorial, also in Swakopmund, to highlight the crimes committed by the former German heroes (Zuern 2017). The Namibian government has responded to this growing activism by attempting to engage the genocide without letting it

13 Author fieldnotes, Okakarara, Namibia (August 23, 2008).

14 Author interview, Israel Kaunatjike, Berlin, Germany (April 25, 2009); author interview Omuiingona Uahimisa Kaapehi, Swakopmund, Namibia (March 17, 2017); author interview, Ngondi Kamatuka, via phone (July 20,2018). 
dominate its preferred independence narrative. The nicknamed "Chamber of Horrors" within the Independence Museum depicts victims of incredible suffering but there is no hero or detailed history. Outside the museum and in front of the old German fort, a new genocide memorial depicts lynched African bodies hanging from a tree and European men standing with guns. Atop the memorial stand sculptures of an African man and woman side by side breaking the chains that have held them. The inscription reads: "Their Blood Waters our Freedom.” The contrast is clear between brutal oppression and death on the one hand and freedom on the other, but the victims and heroes remain anonymous.

Activists seeking to draw attention to the genocide against the Ovaherero and Nama also employ images of starved, chained human bodies to underline the need for action. But they painstakingly document their history. This was detailed, in addition to numerous public fora, academic and journalistic works, in a class action complaint submitted to the US District Court in the Southern District of New York..$^{15}$ The claim is on behalf of "all Ovaherero and Nama peoples for damages resulting from the horrific genocide and unlawful taking of property in violation of international law by the German colonial authorities during the 1885 to 1909 period in southwestern Africa ... now Namibia” (Rukoro et al. 2018, par 1).

A key challenge to both the legal case and broader claims for reparations has been that the genocide occurred more than a century ago, prior to the 1948 Convention on the Prevention and Punishment of the Crime of Genocide. But the presence of victims' descendants in the United States, and the clear violation of international law at the time has allowed the plaintiffs to continue to pursue the action (Goldmann 2018). During the genocide, approximately three hundred Ovaherero and Nama victims of the Shark Island concentration camp were decapitated so that their skulls could be shipped back to Germany for "scientific" research (Rukoro et al. 2018, par 15). This eugenics research was intended to demonstrate the superiority of white Europeans over black Africans. At the time, there was a considerable and profitable trade in human bones. Perhaps hundreds of Ovaherero and Nama skulls, among thousands of other peoples, are still housed in German and other European museums today. Importantly for the class action suit in New York, New York's Museum of Natural History has also admitted to possessing Ovaherero and Nama skulls (Gross 2018). One skull has a price written on it in Reichsmark, proof of

15 The claim was filed in the United States rather than in Germany due to the ability of American lawyers to take the case on contingency; a contingent fee is paid to the lawyers only in the case of recovery. German law prohibits contingent fees. This made filing suit in Germany far too expensive for members of the Ovaherero and Nama communities. 
the trade. This commercial activity that brought Ovaherero and Nama skulls to New York has been crucial to the Plaintiffs' argument for standing in US court. While Judge Swain ruled in March 2019 that the wealth of evidence presented was significant, she deemed it insufficient to overcome Germany's sovereign immunity (Rukoro et. al. 2019). The plaintiffs filed an appeal.

The presence of victims is legally significant; it is also rhetorically and emotionally powerful. In 2006, Ovaherero Paramount Chief Riruako argued in the Namibian Parliament that victimhood extends to the present generation. His statement motivated MPs to overwhelmingly endorse a demand for reparations.

Some of us tend to think that only the dead are victims. When children lose parents, that loss is not only felt by the family and community, but also by the generations to come. When people are displaced, they lose their sense of security and belonging. They experience fear and anxiety and lose hope for the future. As a result, they are deprived of knowledge, goals and aspirations which could help them to build the future and wealth of their families and communities.

"We all stand on the shoulders of those who came before us - people whose lives and accomplishments had been destroyed, whose wealth had been stolen, and who thus had nothing to stand on. They had nothing to leave as their legacy, and we as their heirs have less to build on for our children and the generations to come" (Riruako 2006).

According to this argument, it is the victims of the genocide who have brought their case to the people and to the court. The plaintiffs of the ongoing legal action have detailed the impact of these crimes. In a meeting after court, at the New York City Bar Association, Chief Johannes Isaack recounted the material deprivations and suffering in his community, arguing: "I feel the pain today myself." "16 Paramount Chief Vekuii Rukoro, visibly moved by Isaack's statement, concluded: "We actually consider ourselves direct victims and substantial victims." ${ }^{\text {17 }}$

The challenge for human rights campaigns is to provoke sympathy and outrage for the victims in order to mobilize action without denying all agency to those victims: the hero-victim rhetorical dilemma. The resilience to survive, continue, and pursue justice turns victims into heroes of endurance. These heroes challenge not just former colonial-era German heroes but also the centrality of SWAPO heroes to national liberation. If others struggled earlier,

16 Author fieldnotes, New York City Bar Association (January 25, 2018).

17 Ibid. 
suffered more, and in so doing made greater contributions to the liberation of Namibia, the dominant national narrative so crucial to SWAPO Party's electoral campaigns would be undermined.

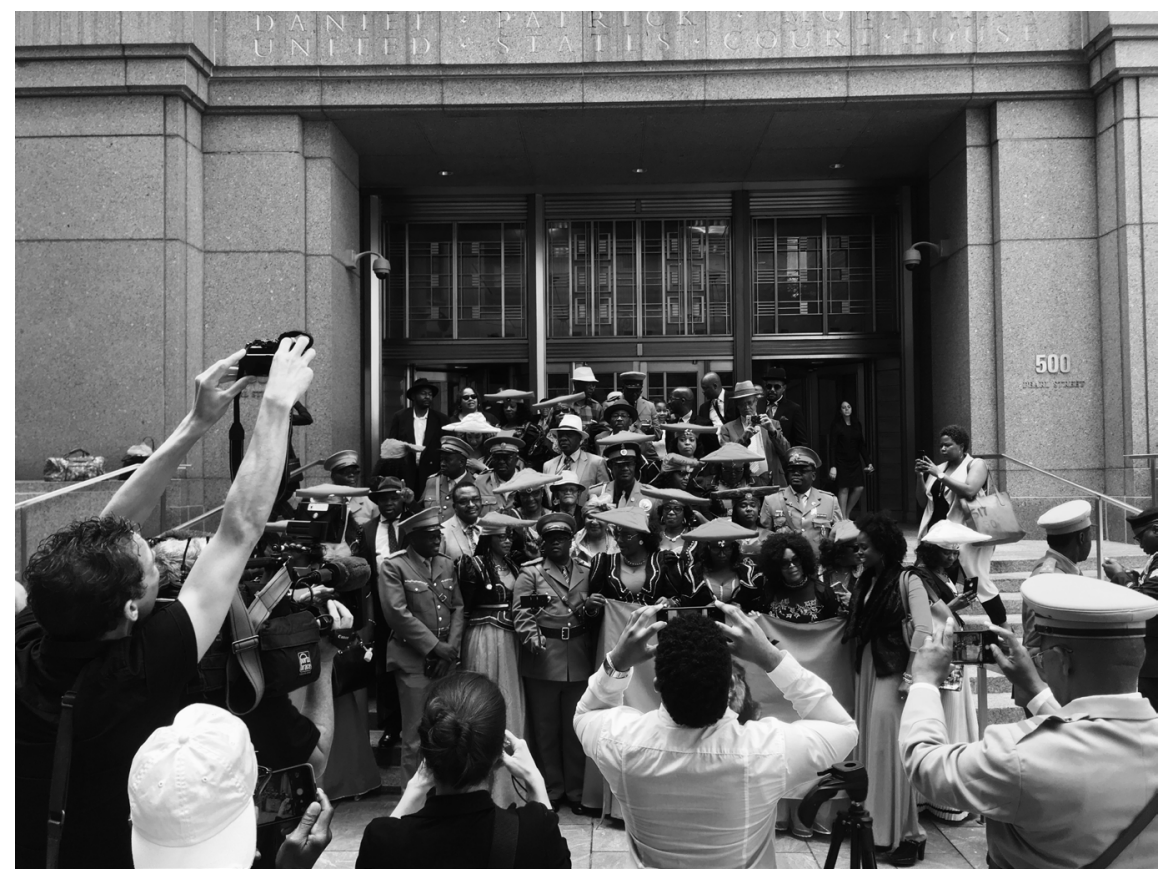

"Direct victims" being photographed in front of courthouse, New York City (2018)

\section{Conclusion: Characters in Divided Nationalism and Popular Struggles}

With Namibian independence, the cast of public heroes changed dramatically. Liberation leaders took central stage and the state built monuments to honor these leaders. Public responses varied. While newspaper reporting, public commentary and author interviews all demonstrate strong support for a postcolonial, post-apartheid narrative that illuminates the domestic struggles for freedom and the sacrifices that many made, the question of who should receive center stage within this narrative remains highly contentious. Ordinary Namibians rarely go to Heroes Acre, even as the state continues to bury its chosen heroes there. The centrally located Independence Memorial Museum receives far more visitors, but it has also been criticized for narrowly focusing on SWAPO's actions, particularly those of its military wing, PLAN, while ignoring civilian struggles. 
While the state has softened its initially exclusive narrative to recognize a wider range of heroes, the most contentious challenge to the dominant narrative continues to emanate from minority communities, particularly Ovaherero and Nama activists. They have employed characters, both victims and heroes of endurance, on the global stage to demand political recognition and monetary compensation for genocide. They have drawn attention not just through the media and detailed historical accounts but also in court where the presence of victims in the United States is crucial to the continuing legal process against the German state. The contrast between the state's definition of Namibia's central heroes and those that minority communities celebrate is of course not specific to Namibia alone, but it is particularly clearly presented in this case with its contrasting memorials, celebrations and Heroes' Days.

Authors such as Gellner, Anderson, and Chaterjee have provided a rich ground to consider both the broad currents and countercurrents of nationalism. A focus on specific heroes and the controversies surrounding them draws our attention to focal points of divided nationalism. The changing popular legitimacy of particular heroes and monuments can provide unanticipated insights into these divisions. Debates over which monuments to remove, from the American South to Southern Africa, point to those aspects of history that are most contentious and also to the communities whose political power is being most directly challenged. Movement organizations as different as Black Lives Matter in the United States and the Ovaherero Genocide Foundation in Namibia focus on challenging long accepted heroes and drawing attention to heroes previously only recognized within their communities. By doing so, they threaten to upend the status quo.

Victims too, play a central and often overlooked role in defining nationalism. Victims form the basis for narratives of who the nation must defend. When victims become heroes of endurance, as we have detailed, they can become the focal point of the very definition of a nation. For movements, victims are crucial to calls for justice. The recalling and replaying of victim experiences evokes strong emotions that can draw new supporters to their struggle. This has been demonstrated again in 2020 as the police killing of George Floyd in the United States led to an unprecedented wave of protest in defense of black lives not just in the US but in many cities around the world. Victims or their descendants may also become key players in legal processes and demands for reparations. Whether or not legal cases such as that filed by the Ovaherero and Nama communities in the Southern District Court of New York succeed is often secondary to the role these cases play in attracting media attention and mobilizing supporters. In the Namibian case, these claims challenge the 
state's special relationship with Germany which includes large aid packages. This helps to explain the government's contradictory responses to the aggrieved communities' demands.

Public characters are crucial but not limited to nation-building. They appear in many if not in all strategic arenas, from law courts to the media, from wartime mobilization to electoral campaigns. An infinite variety of political plots are generated from the interactions of such character tropes, which exert a fascination not only for their familiarity but for the emotions they demand. Some of these plots are basic: the triumph of heroes over villains, the evolution of victims into heroes, the conversion of bad guys into good. They inspire action, summarize history, and arouse passions. Public characters have a moral and symbolic power that no nation-new or old—can do without.

\section{Acknowledgments}

We thank research assistants Harry Barrick, Katherine McGuire, and Nicole Mngodo. Special thanks to Joshua Forrest for his insightful comments on an earlier draft of this article and to our anonymous reviewers.

\section{Bibliography}

Anderson, Benedict. 1991. Imagined Communities: Reflections on the Origin and Spread of Nationalism. London: Verso.

Becker, Heike. 2011. "Commemorating Heroes in Windhoek and Eenhana: Memory, Culture and Nationalism in Namibia, 1990-2010". Africa 81, 4.

Becker, Jo. 2013. Campaigning for Justice: Human Rights Advocacy in Practice. Stanford: Stanford University Press.

Bley, Helmut. 1968. Kolonialherrschaft und Sozialstruktur in Deutsch-Südwestafrika 18941914. Hamburg: Leibniz Verlag. (English edition: 1971. South-West Africa under German Rule 1894-1914. Evanston: Northwestern University Press.)

Böhlke-Itzen, Janntje. 2004. Kolonialschuld und Entschädigung. Der deutsche Völkermord an den Herero 1904-1907. Frankfurt am Main: Brandes \& Apsel.

Chaterjee, Partha. 1993. The Nation and its Fragments: Colonial and Postcolonial Histories. Princeton: Princeton University Press.

Drechsler, Horst. 1980. Let us die fighting: the struggle of the Herero and Nama against German imperialism (1884-1915). London: Zed Press.

Erichsen, Casper. 2008. "What the Elders Used to Say" Namibian Perspectives on the Last Decade of German Colonial Rule. Windhoek: Namibia Institute for Democracy and the Namibian-German Foundation.

Fanon, Frantz. 2004. The Wretched of the Earth. New York: Grove Press.

Förster, Larissa. 2010. Postkoloniale Erinnerungslandschaften: Wie Deutsche und Herero in Namibia des Kriegs von 1904 gedenken. Frankfurt: Campus Verlag. 
Gellner, Ernest. 1983. Nations and Nationalism. Ithaca: Cornell University Press.

Gewald, Jan-Bart. 1999. Herero Heroes: A Socio-Political History of the Herero of Namibia 1890-1923. Oxford: James Currey.

Gewald, Jan-Bart. 2000. "We Thought We Would be Free" Socio-Cultural Aspects of Herero History in Namibia 1915-1940. Köln: Rüdiger Köppe Verlag.

Gewald, Jan-Bart. 2003. "Herero genocide in the twentieth century: politics and memory", in J. Abbink, M. de Bruijn \& K. van Walraven, eds. Rethinking Resistance: revolt and violence in African history. Leiden: Brill, 279-304.

Goldmann, Matthias. 2018. "The Ovaherero and Nama Peoples v. Germany - Declaration of Matthias Goldmann before the SDNY Court (April 25, 2018)”. Available at SSRN: https:// ssrn.com/abstract=3169852 or http://dx.doi.org/10.2139/ssrn.3169852

Grabar, Henry S. 2014. "Reclaiming the city: changing urban meaning in Algiers after 1962" Cultural Geographies 21, 3, 389-409.

Gross, Daniel A. 2018. "The Troubling Origins of the Skeletons in a New York Museum” New Yorker (January 24).

Hobsbawm, E. J. 1992. Nations and Nationalism Since 1780: Programme, Myth, Reality. Cambridge: Cambridge University Press.

Hopwood, Graham. 2014. "From North Korea with Weirdness” Insight Namibia (May).

Jasper, James M., Michael P. Young, and Elke Zuern, 2018. "Character Work in Social Movements" Theory and Society 47, 1, 113-131.

Jasper, James M., Michael P. Young, and Elke Zuern. 2020. Public Characters. New York: Oxford University Press.

Kössler, Reinhart. 2007. "Facing a Fragmented Past: Memory, Culture and Politics in Namibia" Journal of Southern African Studies 33, 2, 361-382.

Marschall, Sabine. 2010. Landscape of Memory: Commemorative Monuments, Memorials and Public Statuary in Post-Apartheid South Africa. Brill: Leiden.

Marx, Anthony. 2003. Faith in Nation: Exclusionary Origins of Nationalism. New York: Oxford University Press.

McGarr, Paul M. 2005. “'The Viceroys are Disappearing from the Roundabouts in Delhi': British symbols of power in post-colonial India” Modern Asian Studies 49, 3.

Melber, Henning. 2005. "Namibia’s Past in the Present: Colonial Genocide and the Liberation Struggle in Commemorative Narratives" South African Historical Journal 54: 91-111.

Melber, Henning. 2015. Understanding Namibia: The Trials of Independence. New York: Oxford University Press.

Mupetami, Limba. 2014. "A Trip Though Namibia’s History at the Independence Memorial Museum" The Namibian, August 5.

NSR cite!

Niezen, Ronald. 2010. Public Justice and the Anthropology of Law. New York: Cambridge University Press.

Olusoga, David and Casper Erichsen. 2010. The Kaiser's Holocaust - Germany's Forgotten Genocide and the Colonial Roots of Nazism. London: Faber and Faber, 149-50. 


\section{Journal of Nationalism, Memory \& Language Politics 14(1)}

Olusoga, David. 2017. "Germany comes to terms with its forgotten Namibian death camps" The Guardian, January 14.

Pohamba, Hifikepunye. 2014. "Statement By His Excellency Dr. Hifikepunye Pohamba, President of the Republic of Namibia on the Occasion of the Inauguration of the Genocide Memorial Statue, the Sam Nujoma Statue and the Independence Memorial Museum” (March 20).

Riruako, Kuaima. 2006. "Motion on the Ovaherero Genocide" National Assembly of the Republic of Namibia (September 19).

Rukoro, Vekuii, Johannes Isaack, Barnabas Veraa Katuuo against Federal Republic of Germany. Amended Class Action Complaint Civ. No. 17-0062. United States District Court Southern District Court (February 14, 2018).

Rukoro, Vekuii et al v. Federal Republic of Germany. No. 17 CV 62-LTS United States District Court, Southern District of New York (2019).

Sarkin, Jeremy and Carly Fowler. 2008. "Reparations for Historical Human Rights Violations: The International and Historical Dimensions of the Alien Tors Claims Act Genocide Case of the Herero of Namibia" Human Rights Review 9, 331-360.

Saul, J. and C. Leys. 2003. "Lubango and after: 'forgotten history' as politics in contemporary Namibia" Journal of Southern African Studies: 29, 2, 333-353.

Savage, Kirk. 1997. Standing Soldiers, Kneeling Slaves: Race, War, and Monument in Nineteenth-Century America. Princeton, NJ: Princeton University Press.

Schwartz, Barry. 2008. Abraham Lincoln in the Post-Heroic Era. Chicago: University of Chicago Press.

Smith, Anthony D. 1986. The Ethnic Origins of Nations. Oxford: Blackwell Publishers.

Snee, Brian. 2015. "Saving the Emancipator" Rhetoric and Public Affairs 18, 1, 141-45.

Southall, Roger. 2013. Liberation Movements in Power: Party and State in Southern Africa. Woodbridge, James Currey.

Southern Poverty Law Center. 2019. "Whose Heritage? Public Symbols of the Confederacy" (February 1) https://www.splcenter.org/20190201/whose-heritage-public-symbols-confederacy.

Springer, Nick, Robert Rodriguez and Ngondi Kamatuka. 2017. "The Ovaherero/Nama Genocide: A Case for an Apology and Reparations" European Scientific Journal June, 120146.

Steinmetz, George. 2008. "Harrowed landscapes: white ruingazers in Namibia and Detroit and the cultivation of memory" Visual Studies, 23, 3, 211-37.

Steinmetz, George and Julia Hell. 2006. "The Visual Archive of Colonialism: Germany and Namibia" Public Culture 18, 1.

Van der Hoog, Tycho. 2019. Monuments of power. The North Korean origin of nationalist monuments in Namibia and Zimbabwe. Leiden: Afrika Studiecentrum.

Werbner, R.P. 1998. "Smoke from the barrel of a gun: postwars of the dead, memory and reinscription in Zimbabwe", in R. Memory and the Postcolony: African anthropology and the critique of power. London: Zed Books, 71-102. 
Elke Zuern, James M. Jasper Heroes and Victims in Divided Nationalism: The Case of Namibia

Wieczorek-Zeul, Heidemarie. 2004. "Speech by Federal Minister Heidemarie WieczorekZeul at the commemorations of the 100th anniversary of the suppression of the Herero uprising, Okakarara, on 14 August 2004".

Zeller, Joachim. 2008. “The German Rider - An Apolitical Soldiers' Memorial?” Namibian Sept. 12.

Zimmerer, Jürgen. 2004. "Colonialism and the Holocaust. Towards an Archaeology of Genocide" in Genocide and Settler Society: Frontier Violence and Stolen Indigenous Children in Australian History, A. Dirk Moses, ed. Oxford: Berghahn Books, 49-76.

Zuern, Elke. 2012. "Memorial Politics: Challenging the Dominant Party's Narrative in Namibia." Journal of Modern African Studies 50, 3, 493-518.

Zuern, Elke. 2017. "Namibia's Monuments to Genocide” Dissent (June 13). 